\title{
Ellipsis
}

2021

\section{A Fragmented Autobiography of a Monster and his Creator: the Origins of Mary Shelley}

Madeleine Hollis

Follow this and additional works at: https://scholarworks.uno.edu/ellipsis

\section{Recommended Citation}

Hollis, Madeleine (2021) "A Fragmented Autobiography of a Monster and his Creator: the Origins of Mary Shelley," Ellipsis: Vol. 46 , Article 23.

DOI: https://doi.org/10.46428/ejail.46.23

Available at: https://scholarworks.uno.edu/ellipsis/vol46/iss1/23

This Essay is brought to you for free and open access by the Department of English and Foreign Languages at ScholarWorks@UNO. It has been accepted for inclusion in Ellipsis by an authorized editor of ScholarWorks@UNO. For more information, please contact scholarworks@uno.edu. 


\section{Quarante Club Prize Winner}

\section{A Fragmented Autobiography of a Monster and His Creator: The Origins of Mary Shelley by Madeleine Hollis}

At the forefront of Mary Shelley's 1818 novel Frankenstein, there lies a question of what Shelley refers to in the novel as "accursed origins." The story of Victor Frankenstein and his monster has long been hailed one of the great gothic tales of all time, but the story is not simply a tale of horror, extending instead into the question of moral vs. amoral creationism. Far surpassing a simple ghost story, Frankenstein can be seen more as a glimpse into Shelley's own life, "a sublimated afterbirth, in which the author expels her own guilt both for having caused her mother's death and for having failed to produce a healthy son for Percy" (Ellen Moers, quoted in Hoeveler 47). In the novel, Shelley fragments her own history, lending pieces of herself to an assortment of characters in order to create a whole mirrored image of her life.

Although this is a novel of fantastical ideas and creatures, it is not one which operates entirely outside the realm of reality. In fact, the central idea of the story lies not in creating a fearful and inhumane creature but in the monster's own search for humanity. The creature, then, is not the monster of yore, who had no desires but to kill the protagonist, but instead a mere child, searching for compassion from both his creator and the world in which he so desperately wishes to fit. In order to understand the importance of this tragedy of motherlessness, one must understand that the tale "embodies the only form she knew- the unformed, inchoate existence of childhood" (Brown 145). Shelley's childhood was not a particularly bright one, as her birth led to the death of her mother, and she was left with a somewhat strict patriarch. These anxieties, and the desire to fill some place in the soul that the mother has left, are commented on subtly throughout the novel.

While different characters in the novel mirror different aspects of her life, Shelley's personal grievances surrounding the loss of her first child are most clearly shown by the creature. In Steven Lehman's essay about the novel, he states that the monster might parallel Shelley's first experience as a mother, as the infant "embod[ies] the monstrosity of an untimely death" as well as the "socially legislated 'monstrosity' [of] not enjoying legitimate status" since Shelley and Percy were not married at the time of the child's birth (49). The creature is never accepted in society, which would have indeed been a struggle for her own child as she lacked legitimacy, and was also not truly accepted by his creator. Shelley, herself, spent only a few short weeks with her first child, and so the idea that she never truly accepted the tragedy of what befell the infant is not unbelievable. However, Shelley's anxieties about being a mother are portrayed more clearly by Victor Frankenstein, the parent figure of the story.

Shelley's experience with her own children is thought by many to be where much of Victor Frankenstein's motivation stems from. Her own inability to produce a child for her husband may have been what led her to create the character of Frankenstein, who "yearned for the existential security of elemental procreative power in the same way she herself did" (Lehman 50). By placing these desires into the form of a male character, we are allowed a glimpse into her 
deep insecurity regarding childbearing. Perhaps this is why Shelley is seen now as relating most to Victor Frankenstein rather than any of the female characters in the novel. As a result of her difficulty in creating a child, she "was forced by fate to identify with the basic procreative frustrations of men, but she also felt the instinctive drive to become a mother and confirm the natural monopoly of her gender" (Lehman 50).

Though Shelley's insecurities about motherhood and childhood are more generously explored in the forms of Frankenstein and his creation, the female characters in the novel do deal with many of the same situations that Shelley experienced in her own life. Safie, much like the monster, is of ultimate "otherness" because of her Arabian ethnicity. Through the monologue given by the creature, readers are given a thorough personal history on what led Safie to become such a prominent figure both in the creature's life and in the story itself. The history of Safie's parents, and, more specifically, her mother, parallels Shelley's mother, Mary Wallstonecraft, a distinguished feminist and literary icon. Much like Wallstonecraft, Safie's mother "taught her to aspire to higher powers of intellect and independence of spirit, forbidden the female" (Shelley, quoted in Zonana 169). Wallstonecraft's early death did not mean that Shelley was ignorant of her teachings but, instead, that she was taught this "intellect and independence" through studying her mother's works. It is in this way that we see how the letters parallel Shelley's own mother's teachings, as they "pointedly express a specific, fundamental feminist message identical to a key premise in Mary Wallstonecraft's $A$ Vindication of the Rights of Women: that women have rational souls" (Zonana 171).

The idea of women being rational and intelligent beings is explored subtly throughout Frankenstein, causing many to question whether or not the text is consciously feminist. The most direct presentation of this idea occurs when Frankenstein destroys the creature's mate, claiming that she "in all probability was to become a thinking and reasoning animal," who "might refuse to comply with a pact made before her creation" (Shelley 169). Although the female characters are certainly intelligent and caring people, this is the first statement we see that insinuates some patriarchal fear of female autonomy. The difficulty in claiming whether or not this means that the text is consciously feminist lies in the idea that the novel is linked "not to the author's beliefs but to her situation" (Brown 145). Shelley's entire adolescence consisted of reading her mother's feminist works, texts that were initially criticized and deemed to be overly outspoken. The patriarchal fear of women's independence was shown to Shelley at such a young age that to speak out against it would be entirely natural, if not political.

Safie is not the only female character who can be linked to Shelley. In fact, both Elizabeth and Justine experience tragedies that parallel those that Shelley herself went through. Justine's story is not as direct a parallel to Shelley's as some of the other characters': their similarity lies only in the fact that both character and author have been through a long history of death and loss. Shelley's famously tragic entrance into life was followed by a long list of dead friends and children, including her own first three children, as well as her half sister and husband. Life was, for Shelley, a never ending cycle of loss. It seems that Justine shared this fate, as all of her siblings died as well as Victor's mother and William, both of whom she considered to be family. Though Shelley placed no blame on Elizabeth for Frankenstein's mother's death, Justine is described as believing "that the deaths of her favourites was a judgement from heaven" (Shelley 61). It is possible that the blame which Justine places upon herself mirrors the feelings that Shelley had about her own grief. Justine's death is interesting then, in that she dies an 
innocent woman, forgiven by the family that she loved. Perhaps this is a portrayal of Shelley's own self-forgiveness.

Of course, Justine is not the only female character in the story who experiences great devastation. Elizabeth's close relationship to Frankenstein's mother eventually ends in tragedy, as Madame Frankenstein feels that she must nurse Elizabeth back to health, which causes Madame Fankenstein to contract scarlet fever. The fact that Shelley does not blame Elizabeth leads one to believe that perhaps Elizabeth may also be a personified form of self forgiveness. After Frankenstein's mother's death, Elizabeth sought only to "contribute to the happiness of others, entirely forgetful of herself" (Shelley 39). In this way, Elizabeth becomes the perfect depiction of the "angel of the house," the selfless caretaker which all women were expected to be in these times. This description of Elizabeth is one of the most consciously feminist moments in the novel, as Shelley seems to be critiquing this idea of the angel who is forced to give up her own feelings and desires in order to please the men of the house.

In regards to Elizabeth, there are many moments which pass with such nonchalance on Victor's part that one might miss them entirely. To see her moments of selflessness through the eyes of a male protagonist is to see them as natural and expected. In one instance, Victor claims that he regards her as a prize of sorts, saying "all praises bestowed on her, I received as made to a possession of my own" (Shelley 34). Is this, perhaps, the experience that Shelley herself had with her husband or simply a critique on men's possessiveness over their wives? In the introduction to the third edition of the novel, Shelley writes that she "did not owe the suggestion of one incident, nor scarcely of one train of feeling, to [her] husband," so it is likely that Victor's treatment of Elizabeth is meant to reflect the expectations of most men rather than the truth of her own marriage (229). Another instance of his selfishness in regards to his wife comes at the end of the novel, when he marries Elizabeth without considering that she may die at the hands of the monster. The way in which she died can also be seen as commentary on female oppression, as she was quite literally silenced by the monster whose "murderous mark" was left on her neck. This mark is left on both William and Henry as well, the only difference being that Elizabeth's scream for help is cut off, whereas we do not directly see this happen to the male characters.

If one is to look into the existence of the oppressed female presence in the story, then one must also look at the question of whether the insecurity portrayed by Frankenstein relates not only to Shelley's history with loss, but her status as a female writer. Some critics refuse the idea that Shelley felt insecure in her writing, as she was encouraged to create from such a young age. Shelley's half-sister makes this clear in a statement about their childhood: "In our family, if you cannot write an epic poem or novel, that by its originality knocks all other novels on the head, you are a despicable creature not worth acknowledging" (Claire Clairmont, quoted in Poovey 332). As the child of two famous literary figures, Shelley's decision to write would not only be encouraged, but expected. This, however, applies strictly to Shelley's familial life and not to the society in which she was raised. Outside of her family, "this pressure to be 'original' was contradicted by the more prevalent social expectations that a woman conform to the conventional feminine model of propriety, that she be self-effacing and supportive, devoted to a family rather than to a career" (Poovey 332). Once again, the idea of the "angel of the house" rears its head. Elizabeth, though similar to Shelley in some ways, is more so the perfect woman that Shelley herself could not be. 
The anxiety that comes with being a female writer in a time when women with careers were looked down upon is certainly portrayed by Victor's anxiety about his creation.

Frankenstein's grief over creating a "wretch whom with such infinite pains and care [he] had endeavoured to form," mirrors the feeling that Shelley expresses in her introduction to the third edition (Shelley 58). Shelley concludes the introduction by saying "now, once again, I bid my hideous progeny go forth and prosper"-nearly the same sentiment that Frankenstein displays when realizing that his creature is alive, although he does not wish for it to prosper (228). Both Frankenstein and Shelley exhibit some level of distaste, or even disgust, with the creation which they spent so long laboring over. This is surely not to say that Shelley found the novel shameful in any other way than that it was looked down upon by male critics at the time.

The fact that Shelley was married to a renowned literary figure and friends with many others, such as Lord Byron, with whom she competed in the ghost story contest, must also factor into her creative insecurity. With the exception of a rare few famous female writers like Jane Austen, literature was almost completely a boys club — one with which Shelley was well acquainted. To live up to the standards of Percy and Lord Byron, who were both already famous at the conception of Frankenstein, would have certainly been enough to make Shelley fearful of the quality of her own work, or at the very least, at how it might be received by a society that expected women to be seen instead of heard. By creating a character like Frankenstein, who accomplished something great and then was ruined for it, readers see how Shelley is able to "simultaneously fulfill and punish her desire for self-expression" (Poover 332).

Through exploring the different desires, anxieties, and devastations of the characters in the novel, one is allowed a glimpse into the life of Mary Shelley. By dismembering her own identity, much like the creature in the story, Shelley creates a full view of both her history and her present through the fragmented pieces of herself which we find in the characters she has created. It is in this way that readers can begin to answer the question that has been begged since its first publication - is this a consciously feminist text? It is a story that relies heavily on Shelley's own situation, but this does not mean that there is no room left to explore her beliefs, which did indeed include criticism of female oppression. While this was clearly not meant to be a novel of autobiographical nature, Frankenstein succeeds in creating a nearly complete mosaic of Shelley's inner and outer life. 


\section{Works Cited}

Brown, Marshall. "Frankenstein: A Child's Tale." NOVEL: A Forum on Fiction, vol. 36, no. 2, 2003, pp. 145-175. JSTOR, www.jstor.org/stable/1346124.

Hoeveler, Diane. "Frankenstein, Feminism, and Literary Theory." The Cambridge Companion to Mary Shelley, Jan. 1, 2003, pp. 45-62. https://epublications.marquette.edu/cgi/ viewcontent.cgi?article $=1051 \&$ context=english_fac.

Lehman, Steven. "The Motherless Child in Science Fiction: Frankenstein and Moreau (L'Orphelin De Mère Dans La Science Fiction: Frankenstein Et Moreau)." Science Fiction Studies, vol. 19, no. 1, 1992, pp. 49-58. JSTOR, www.jstor.org/stable/4240120.

Poovey, Mary. "My Hideous Progeny: Mary Shelley and the Feminization of Romanticism." PMLA, vol. 95, no. 3, 1980, pp. 332-347. JSTOR, www.jstor.org/stable/461877.

Shelley, Mary Wollstonecraft, 1797-1851. Frankenstein, Or, The Modern Prometheus: the 1818 Text. Oxford; New York: Oxford University Press, 1998.

Zonana, Joyce. “'They Will Prove the Truth of My Tale': Safie's Letters as the Feminist Core of Mary Shelley's Frankenstein."The Journal of Narrative Technique, vol. 21, no. 2, 1991, pp. 170-184. JSTOR, www.jstor.org/stable/30225329. 